\title{
Results of Treatment with Stereotactic Radiotherapy in Patients with Early-Stage Medically Inoperable Non-Small Cell Lung Cancer
}

\author{
Cengiz Gemici
}

Department of Radiation Oncology, Kartal Dr. Lütfi Kırdar Training and Research Hospital, İstanbul, Turkey

Submitted: 26.12.2016 Accepted: 28.12.2016

Correspondence: Cengiz Gemici, Kartal Dr. Lütfi Kırdar Eğitim ve Araştırma Hastanesi, Radyasyon Onkolojisi Kliniği, İstanbul, Turkey

E-mail: cegemici@yahoo.com

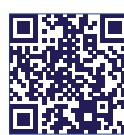

Keywords: Early stage lung cancer; non small cell lung cancer; stereotactic radiotherapy.

\begin{abstract}
Objective: This study aimed to determine local control and overall survival of patients with medically inoperable early-stage non-small cell lung cancer treated with stereotactic ablative radiotherapy.
\end{abstract}

Methods: A total of 35 patients [6 (17\%) females and 29 (83\%) males] with medically inoperable early-stage non-small cell lung cancer and who were treated with stereotactic ablative body radiotherapy by a CyberKnife robotic radiotherapy machine between 2009 and 2015 were evaluated retrospectively.

Results: The median age of patients was 69 (55-83) years. The ECOG performance score of $24(67 \%)$ and I I (33\%) patients were I and 2, respectively. Tumor was staged as CTI in I9 (54\%) patients and cT2 in 16 (46\%) patients. Tumor was centrally located in 6 (17\%) patients and peripheral in 29 (83\%) patients. The mean planning target volume (PTV) was $124.1 \mathrm{~mm}^{3}$ $\left(14.5-233.7 \mathrm{~mm}^{3}\right)$. As regards the tumor-tracking system, X-Sight lung tracking system was used in 31 (88\%) patients, gold fiducials in $3(9 \%)$ patients, and X-Sight spine tracking system in I (3\%) patient. 43 Gy (30-60 Gy) radiotherapy has been described to $81 \%$ isodose line (70-92\%) and delivered in 3 and 5 fractions to 33 (94\%), and 2 (6\%) patients respectively.

Conclusion: During 21 months median follow-up time (2-5I months) local recurrence was observed in only $2(5 \%)$ patients. The 2 -year local control rate was $93.4 \%$, the 2 -year overall survival rate was $45 \%$, and the mean survival time was 21.4 months. Grade 3 toxicity was observed in only two patients; no grade 4-5 toxicity was observed. The effect of age, performance status, T stage, PTV volume, and radiation dose over local control and overall survival were investigated, but no significant correlation was found. A high local control rate with no major toxicity was obtained by stereotactic ablative body radiotherapy in the patients with medically inoperable early-stage non-small cell lung cancer.

\section{INTRODUCTION}

Lung cancer is the deadliest cancer type in both men and women. ${ }^{[1]}$ Surgery is the standard treatment method for early-stage lung cancer. ${ }^{[2]}$ Increased awareness and increased use of screening by tomography have led to increased incidence of cases with early-stage lung cancer. ${ }^{[1,2]}$ The number of patients who cannot be medically operated is increasing with the increase in elderly population. In this group of patients who could not undergo surgery due to medical reasons, classical fractionated radiotherapies were applied, but the results were not as successful as obtained by surgery. ${ }^{[3]}$ High dose fractionated radiotherapy focusing on tumor can be applied safely and more frequently due to the development in radiotherapy technologies with the guidance of imaging and treatment planning. ${ }^{[4,5]}$ Basically, 
stereotactic radiotherapy can be described as an image guided delivery of multiple bundles of high-dose radiation beams on tumors localized three-dimensionally. ${ }^{[6,7]}$ Stereotactic radiotherapy was first used in treating localized brain tumors in the 1990s, and with the advent of imaging and computer technologies, stereotactic radiotherapy have been successfully applied to tumors located in other organs of the body besides extracranial regions. ${ }^{[6,7]}$

Currently, stereotactive ablative body radiotherapy (SABR) is an alternative to surgery in patients with non-small cell lung cancer who are medically inoperable or do not accept surgical resection and for small tumors with no lymph node involvement. ${ }^{[7-9]}$

\section{MATERIAL AND METHODS}

Thirty-five patients diagnosed with early stage non-small cell lung cancer and not suitable for surgery due to medical comorbidities were treated with CyberKnife radiotherapy machine and were analyzed retrospectively.

Several parameters such as age, sex, tumor localization, $T$ stage, performance scores, planned target volume, system used for tumor tracking, number of fractions, prescribed radiation dose, follow-up times, survival, local relapse, and treatment-related toxicities were evaluated in these patients.

Three different tumor-tracking modalities such as X-Sight lung, gold marker, and $X$-Sight spine can be used as tracking systems in SABR with CyberKnife. The X-Sight lung tumor tracking method is a non-invasive and reliable method in case when the tumor diameter is greater than $1.5 \mathrm{~cm}$, and tumor is peripherally located and not masked by vertebras and heart. The X-Sight spine technique is another noninvasive tumor-tracking method that can be used safely for tumors situated adjacent to the vertebral bones. Since the gold marker placement method is performed by an interventional radiologist and it has a pneumothorax risk, other tumor tracking modalities are preferred if possible.

In our hospital, all patients with lung cancer who were treated with SABR were evaluated in a multidisciplinary tumor board including chest surgeon, interventional radiologist, and medical and radiation oncologists. Medical inoperability criteria were considered as FEVI <I.5L, preoperavitiy FEVI $<40 \%$, or DLCO $<40 \%$. The last decision was made by thoracic surgeon. The cases that were not operated because of cardiac and other medical reasons were evaluated for stereotactic radiotherapy.

The gross tumor volume (GTV) was determined by making a fusion with Positron emission tomogrophy (PET) on planning tomography in the parenchyma window. PTV was obtained by giving $5 \mathrm{~mm}$ margin to GTV due to setup uncertainties and tumor movement. The average tumor vol-
Table I. Patients and treatment characteristics

\begin{tabular}{ll}
\hline Characteristics & $\mathbf{n}$ \\
\hline Median age & 69 (55-83) \\
ECOG performance score & I (24 patients, 67\%) \\
& 2 (II patients, 33\%) \\
T stage & TI (I9 patients, 54\%) \\
& T2 (I6 patients, I6\%) \\
Tumor localization & Central (6 patients, I7\%) \\
Median PTV volume & Peripheral (29 patients, 83\%) \\
Tumor tracking method & I24.I mm ${ }^{3}$ (I4.5-223.7 mm 3 -Sight lung (3I patients, 88\%) \\
& X-Sight spine (I patients, 3\%) \\
& Gold label (3 patients, 9\%) \\
Median SABR dose & 43 Gy (30-60 Gy) \\
Number of fractions & 3 fractions (33 patients, 95\%) \\
& 5 fractions (2 patients, 5\%) \\
\hline
\end{tabular}

ume in the cases was $124.1 \mathrm{~mm}^{3}\left(14.5-233.7 \mathrm{~mm}^{3}\right)$.

An average of $43 \mathrm{~Gy}$ (30-60 Gy) radiotherapy was defined to $81 \%$ isodose line (70\%-92\%) and delivered in 3 and 5 fractions to $33(94 \%)$ and 2 (6\%) patients, respectively.

In patients, the time elapsed until local progression, average survival time, and acute toxicity rates were statistically evaluated. The Kaplan-Meier method was used in the survival analysis. Age, performance score, T stage, PTV, dose effect parameters regarding general survival, and local control were assessed with a univariate analysis.

\section{RESULTS}

The median age of the cases was $69(55-83)$ years [6 (I7\%) females and 29 (83\%) males]. Twenty-four patients (67\%) had ECOG performance score of I, and eleven patients (32\%) had 2. The tumor was staged as cTI (54\%) in 19 patients and cT2 (46\%) in 16 patients. Tumor location was central in 6 patients (17\%), and peripheral in 29 patients $(83 \%)$. The average PTV volume was $124.1 \mathrm{~mm}^{3}$ $\left(14.5-233.7 \mathrm{~mm}^{3}\right)$.

As tumor tracking system, X-Sight lung method was used in 31 (88\%) patients, gold markers in $3(9 \%)$ patients, and X-sight spine method in I (3\%) patient. An average of 43 Gy $(30-60 \mathrm{~Gy})$ radiotherapy was defined to $81 \%$ isodose line (70\%-92\%) and delivered in 3 and 5 fractions to 33 $(94 \%)$ and $2(6 \%)$ patients, respectively. Patient and treatment characteristics were summarized in Table I.

After 21-month mean follow-up time (2-5I months), local relapse was detected in only two patients $(5 \%)$. The 2 -year local control rate was $93.4 \%$. The 2 -year survival 
Table 2. Results

\begin{tabular}{ll}
\hline Results & $\mathbf{n}$ \\
\hline Median follow-up time & 21 months (2-5I) \\
Local recurrence & 2 patients (5\%) \\
2-Year local control rate & $93.4 \%$ \\
Median local control time & 34 months \\
2-Year survival rate & $45 \%$ \\
Overall survival & 21.4 months (I7.5-33.6) \\
Toxicity & $\mathrm{G} 3,2$ patients - G4, No \\
\hline
\end{tabular}

rate was $45 \%$, and the average survival time was found as 21.4 months. Grade 3 toxicity was detected in two patients, and no grade 4-5 toxicity was detected. These results were shown in Table 2.

Effect of age, performance score, tumor stage, PTV volume, and radiation dose on overall survival and local control were assessed, but no significance was detected.

The local control and general survival curves are summarized in Figures $\mathrm{I}$ and 2.

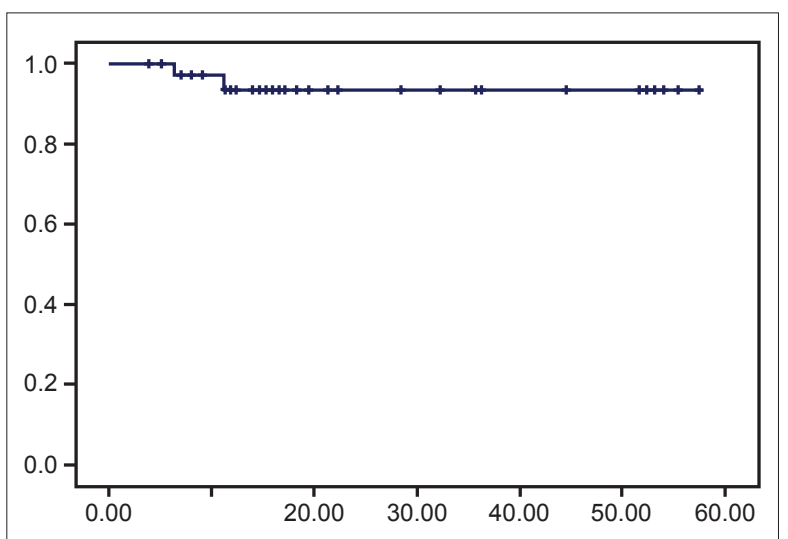

Figure 1. Local control.

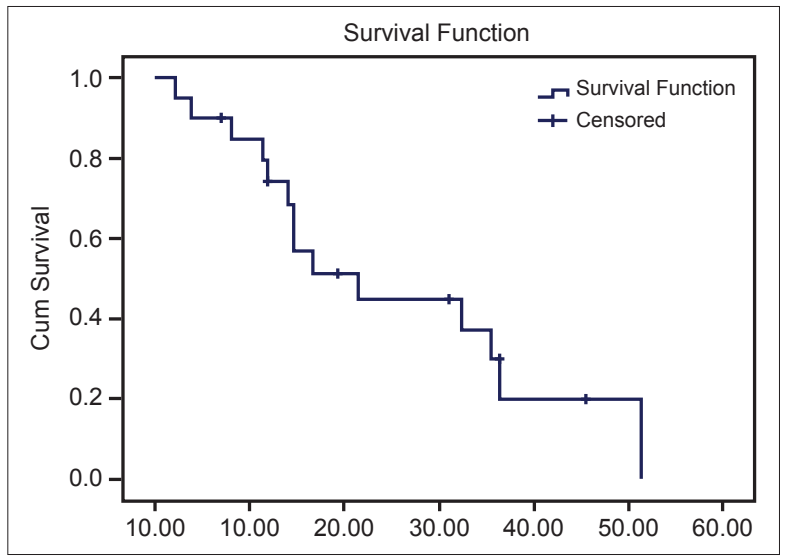

Figure 2. Survival.

\section{DISCUSSION}

In recent years, remarkable changes occurred in earlystage non-small cell lung cancer in parallel with the development in the fields of surgery and radiotherapy. Currently, the application of video-assisted thoracoscopic surgery has significantly reduced surgery-associated morbidities. Conventional fractionated radiotherapy in treating earlystage lung cancer has left its place to stereotactic ablative body radiotherapy, and SABR is the standard treatment for TI,2 tumors (in cases with no lymph node involvement) that cannot be surgically treated for medical reasons. ${ }^{[10]}$ The local control rates obtained with SABR are very good and are similar to those obtained with surgery. ${ }^{[9,10]}$ In the present study, only 2 cases out of 35 patients showed post-treatment failure, and the 2-year local control rate was $93.4 \%$ (Figure I). Although local control rates were high, the overall survival rate was low in the present study (2-year total survival, 45\%). Despite the high success in local control rates, the survival rate is low due to the high non cancer related deaths in these patients. Although local control rates that were obtained with SABR were similar to the rates obtained after surgery, this treatment is still not considered as a standart treatment. This treatment modality is preferred primarily in patients who have comorbidities and are medically inoperable. However, the number of cases who are treated with this technology is rapidly increasing. Current randomized studies in patients with no comorbidities have shown the equivalance of SABR to surgical resection. ${ }^{[4,11]}$ Another advantage of $S A B R$ is the low toxicity rates of this treatment modality, and its easy and safe application in experienced centers. No grade IV toxicity was observed in any of the 35 patients treated in in this study.

In the near future, SABR will become an alternative to surgery, and it will be safely applicable treatment method for cases with early-stage lung cancer.

Authorship contributions

Concept: C.G.; Design: C.G.; Data collection \&/or processing: C.G.; Analysis and/or interpretation: C.G.; Literature search: C.G.; Writing: C.G.; Critical review: C.G.

Conflict of interest

None declared.

\section{REFERENCES}

1. Aberle DR, Adams AM, Berg CD, Black WC, Clapp JD, Fagerstrom $\mathrm{RM}$, et al. Reduced lung-cancer mortality with low-dose computed tomographic screening. N Engl J Med 2011;365:395-409. [CrossRef]

2. Howington JA, Blum MG, Chang AC, Balekian AA, Murthy SC. Treatment of stage I and II non-small cell lung cancer: Diagnosis and management of lung cancer. 3rd ed: American College of Chest Physicians evidence-based clinical practice guidelines. Chest 2013;143(5 
Suppl):278-313.

3. Rowell NP, Williams CJ. Radical radiotherapy for stage I/II nonsmall cell lung cancer in patients not sufficiently fit for or declining surgery (medically inoperable): a systematic review. Thorax 2001;56:628-38. [CrossRef]

4. Solda F, Lodge M, Ashley S. Stereotactic radiotherapy (SABR) for the treatment of primary non-small cell lung cancer; Sytematic review and comparison with a surgical cohort. Radiother Oncol 2015;109:1-7.

5. Potters L, Kavanagh B, Galvin JM. American Society for Therapeutic Radiology and Oncology (ASTRO) and American College of Radiology (ACR) practice guideline for the performance of stereotactic body radiation therapy. Int J Radiat Oncol Biol Phys 2010;76:32632. [CrossRef]

6. Wulf J, Hädinger U, Oppitz U. Stereotactic radiotherapy of extracranial targets: CT-simulation and accuracy of treatment in the stereotactic body frame. Radiother Oncol 2000;57:225-36. [CrossRef]

7. Guckenberger M, Klement RJ, Allgauer M. Applicability of the linear quadratic formalism for modeling local tumor control probability in high dose perfraction stereotactic body radiotherapy for early stagenon-small cell lung cancer. Radiother Oncol 2013;109:13-20.

8. Navarria P, Ascolese AM, Mancosu P. Volumetric modulatedarctherapywithflatteningfilterfree (FFF) beamsforstereotactic body radiationtherapy (SBRT) in patients with medically inoperable early stage nonsmall cell lung cancer (NSCLC). Radiother Oncol 2013;107:414-8. [CrossRef]

9. Amini, A, Yeh, N, Gaspar, L.E. Stereotactic body radiationtherapy (sbrt) for lung cancer patients previously treated with conventional radiotherapy: A review. Radiat Oncol 2014;9:210. [CrossRef]

10. Jones GC, Kehrer JD, Kahn J, Koneru BN, Narayan R, Thomas TO, et al. Primary Treatment Options for High-Risk/Medically Inoperable Early Stage NSCLC Patients. Clin Lung Cancer 2015;16:41330. [CrossRef]

11. Zhang B, Zhu F, Ma X. Matched-paircomparisons of stereotactic body radiotherapy (SBRT) versus surgery for the treatment of early stage non-small cell lung cancer: A systematic review and meta-analysis. Radiother Oncol 2014;112:250-5. [CrossRef]

\section{Tıbbi Nedenlerle Ameliyat Edilemeyen Erken Evre Küçük Hücreli Dışı Akciğer Kanserli Olgularda Stereotaktik Radyoterapi Tedavi Sonuçları}

Amaç: Tıbbi nedenlerle ameliyat edilemeyen erken evre küçük hücreli dışı akciğer kanserli olgularda stereotaktik ablatif vücut radyoterapisinin (SABR) lokal kontrol ve genel sağ kalım üzerindeki etkisi araştırıldı.

Gereç ve Yöntem: 2009-20I5 yılları arasında CyberKnife robotik radyoterapi cihazı ile stereotaktik ablatif radyoterapi uygulanan, tıbbi nedenlerle ameliyat edilemeyen küçük hücreli dışı akciğer kanserli 35 hasta (6 erkek [\% 17], 29 kadın [\%83]) geriye dönük olarak değerlendirildi.

Bulgular: Olguların medyan yaşı 69 (55-83) idi. Olguların ECOG performans skoru 24 (\%67) hastada I, I I (\%33) hastada 2 olarak saptandı. Tümör hastaların 19'unda cTI (\%54), I6'sında cT2 (\%46) olarak evrelendi. Tümör hastaların altısında santral (\% I7), 29'unda periferik yerleşimliydi (\%83). Ortalama planlama hedef volümü (PTV) I24.I mm3 (I4.5-233.7 mm $\mathrm{mm}^{3}$ olarak bulundu. Tedavi sırasında tümör takip sistemi olarak hastaların 3 l'inde (\%88) X-Sight lung, üçünde (\%9) altın işaretleyiciler, birinde (\%3) X-Sight spine tekniği kullanıldı. Hastaların 33'üne (\%94), 3 fraksiyonda, ikisine (\%6) 5 fraksiyonda, \%8I'lik izodoz hattına (\%70-92) ortalama 43 Gy radyoterapi uygulandı (30-60 Gy).

Sonuç: Ortalama 2 I aylık takip süresinde (dağıım, 2-5I ay) iki hastada lokal nüks (\%5) gelişmiştir. İki yıllık lokal kontrol oranı \%93.4'tür, genel sağ kalım oranı \%45, ortalama sağ kalım süresi 21.4 ay olarak saptanmıştır. İki hastada grade 3 toksisite saptanmış olup grade 4-5 toksisite gözlenmemiştir. Genel sağ kalım ve lokal kontrol üzerine yaş, performans durumu, T evresi, PTV volümü, radyasyon dozunun etkisi araştırılmış ancak anlamlılık saptanmamıştır. Erken evre tıbbi nedenlerle ameliyat edilemeyen küçük hücreli dışı akciğer kanserli hastalarımızda stereotaktik ablatif vücut radyoterapisi ile yüksek lokal kontrol oranları sağlanmış ve bu tedavi güvenle uygulanabilmiştir.

Anahtar Sözcükler: Erken evre akciğer kanseri; kü̧̈ük hücre dışı akciğer kanseri; stereotaktik radyoterapi. 